with a probable error from nine measurements of $\mid$ it is surmounted, at two minutes before one is raised $\mid$ The fixing of the standard of time depends on astro0.0074 or an error of one part in 14,630. The angular to the top, and at one o'cloek precisely the ball drops. nounical observations. When the sun is exactly velocity w can with proper instruments be obtained By means of an electric current frow the observatory south-on the meridian, as it is called-the hour is

with great accuracy.
The principal ballistic result obtained from the ex- $\begin{aligned} & \text { accurate time signals are distributed every hour by the twelve o'clock noon. As the movement of the sun ap- } \\ & \text { post office telegraphs to a large number of towns, and }\end{aligned}$ parently fluctuates, astronowers call this apparent periments may be said to be thelocating of a maximum clocks in the metropolis and country are synchonized. noon. At Green wich Observatory to the study of the peint in the velocity curve on waximum point is, in the present experiment, at 6 or 7 four hour clock face, that is, with hours warked from the time. feet from the muzzle of the gun-certainly wore than one totwenty-four, to include a day and nimht; where The way of it is this. There are two finely made 5 feet and less than 10 -orabout 25 calibers in front of the time is exhibjted at any hour when the park is clocks-the solarclock, keeping the solar time, and the 5 feet and less than 10 -or about 25 calibers in front of
the muzzle. The increase in velocity from the muzzle
open for any one who chooses to climb the pleasant to the waximum point is large. Iuore than 40 foot hill and look at it. The sidereal clock is kept as the standard, and every seconds. The muzzle velocity being about 1,600 feet, this increase is about 2.5 per cent of the whole. The decrease in velocity beyond the maximut point is comparatively gradual, obeying the true law of the resistance of the air, so must travel about before th ty is reduced to that which it ac tually had at the muzzle.

This maximum point introduce an error in the present method of obtaining muzzle velocities. velocities, in ty is measured at a distance of 100 to 200 feet and reduced back to the muzzle by formu las. The Frank-

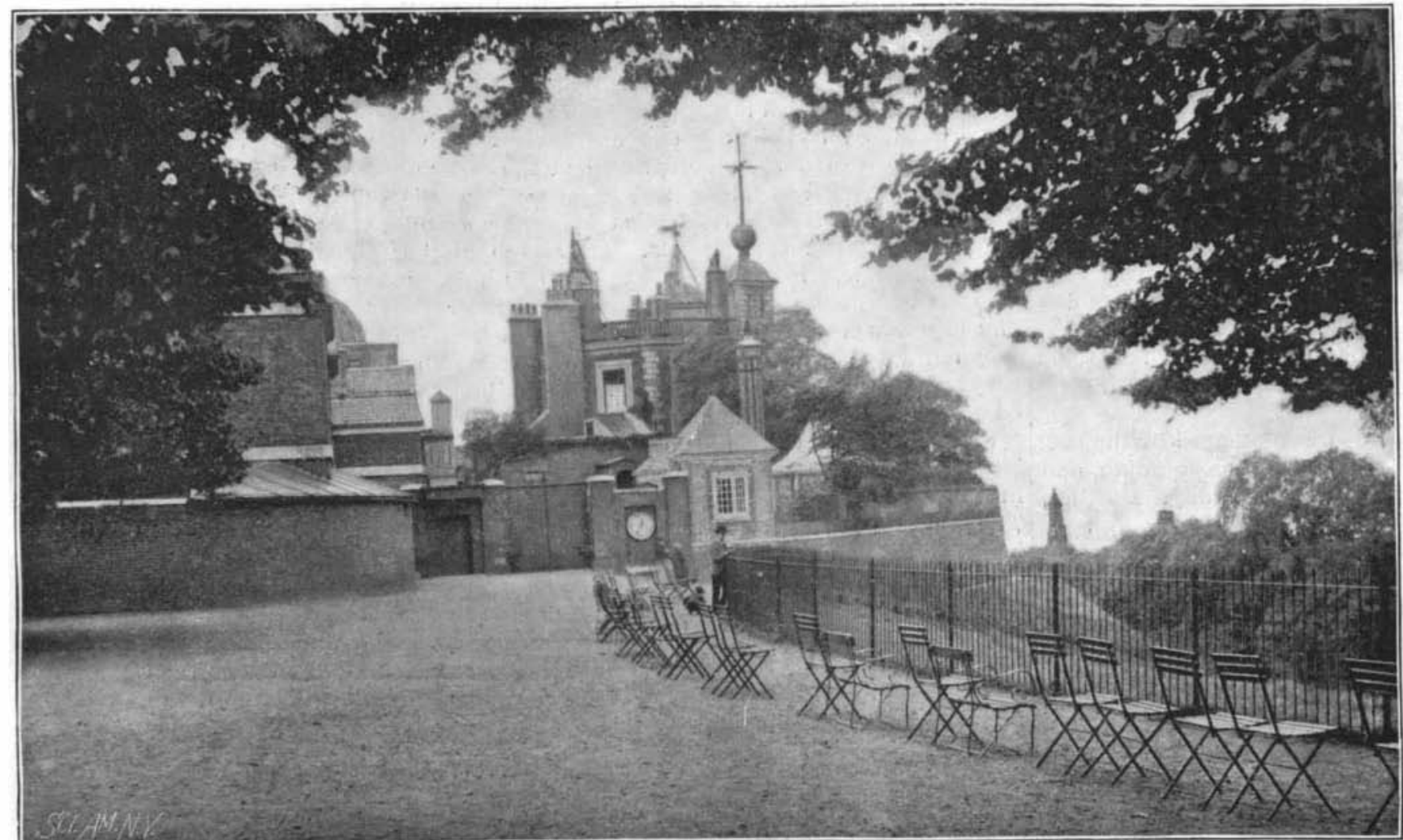

THE ROYAL OBSERVATORY AT GREENWICH. night or day the weather permits, tertuined by comclocks. The error of the solar clock is then corrected. Th e standard time, therefore, is kept for the nation at Greenwich by constant observation of certain stars, checked by observaions of the sun. There are sow two hundred and fifty stars calendared at Greenwich, which are known as clock stars. The ob servations are made with a fine instrument called the transit or meridian circle. Greenwich has the honor of having been the first observatory in the world where a large transit

lin Institute has awarded the John Scott Legacy| The observatory is an oblong edifice, divided into|circle was mounted, viz., in 1850 . Briefly, it is a medal and premium to Lieut. Squier and Prof. four apartments. It is a quiet, retired spot well walled large and fine telescope, mounted between two upCrehore for this apparatus.

THE ROYAL OBSERVATORY AND HOW THEY TEL THE TIME AT GREENWICH BY DR. D. DUNBAR. Greenwich, situate on the winding Thames,five miles city, the astronomers keep the time for half the world. the room in which the telescope is placed can be east-southeast from London, in the Connty of Kent, Greenwich time is the standard for the British nation, opened by a sliding or trap door above it, and thus possesses a large amount of bistorical interest. It is the for British ships at sea, and for the ships of most can expose any point of the meridian.

birthplace of many ilustrious persons, among them other countries as well. Henry the Eighth, Edward the Sixth, Queen Mary, We were received Mr. Queen Elizabeth, and several children of Jawes the mer Royal, and placed in charge of the senior com- Greenwich zenith; and it is when on this center line First. But it is not of departed kings and queens we putor, Mr. H. Furnel, to be escorted over the apart- in their journey from east to west that the sun and propose now to speak, nor of the social attractions of ments. We soon find that his acquaintance with the stars are said to be on the meridian. When the sun is Greenwich. It is a place of reat resort, specially on a interesting and delicate instruments that are ex- on this line, the hour is midday at Greenwich.

Greenwich. It is a place of great resort, specially on a $\begin{aligned} & \text { interesting and delicate instruments that are ex- on this line, the hour is midday at Greenwich. } \\ & \text { plained in turn is much greater than our limited In the eyepiece of the telescope are five wires, one of }\end{aligned}$
bright bank holiday. The observatory building is familiar to every inhab- powers of comprehension. But Mr. Furnel, who has which is exactly on the middle. When, therefore, the itant of the town, and well known to scientific men all becowe a student of the stars, is a patient gentlema: star passes this line, it is at the highest, or crossing over the world. It stands on the spot once occupied who goes to much trouble in his endeavors to initiate the meridian. This, however, is not exactly the same by the tower built by Duke Humphrey. At one time a layman in the mysteries of the heavens. the observatory was furnished with a deep well for the The main question of this paper is how they tell the bably exactly on the meridian line, and the error is observation of stars in the daytime, but the great time at Greenwich, and we shall endeavor to explain corrected by various calculations.

improvement in telescopes rendered this unnecessary, this in popular rather than in scientific language: Connected by electricity with the transit circle is a and it is now arched over. An apparatus has been erected on the eastern turret of the observatory for the purpose of enabling the captains of vessels leaving of enabling the captains of vessels leaving the river to ascertain by it the rate of their chronometers, thus
obviating the necessity of applying at the obobviating the necessity of applying at the observatory. It consists of a large ball of wood lined with leather, which, in order to give prefore one P. M., half way up a pole, by which

*This apparatus is described at greater length and with additional illustrations in SuPPLEMENT, No. 105

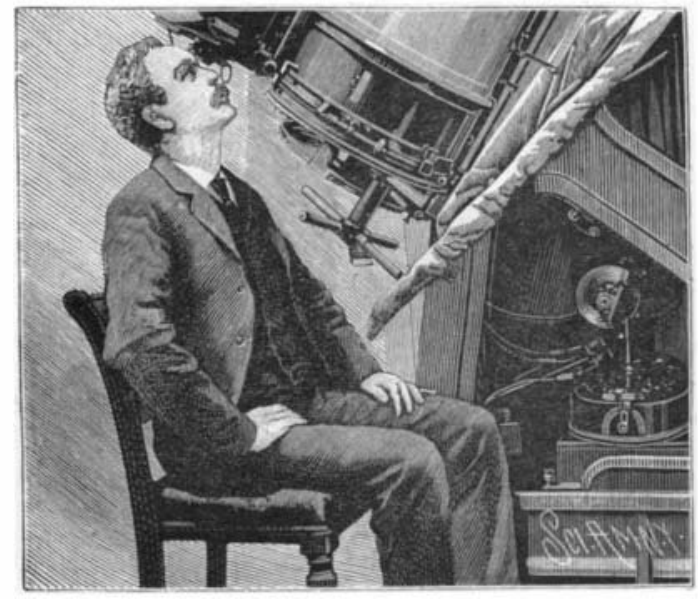

THE GUIDER AND PHOTOGRAPHER AT WORK.

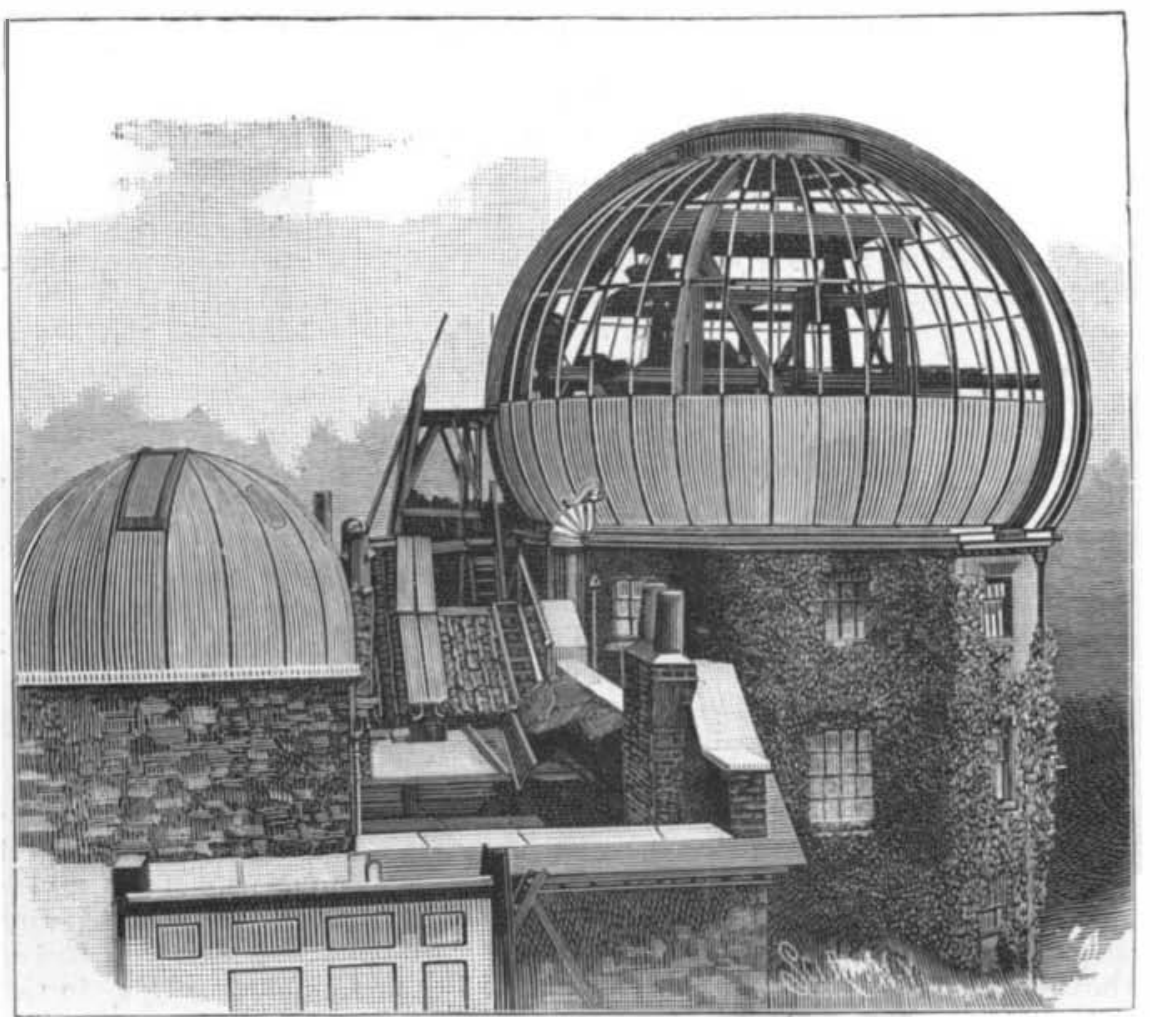

ONE OF THE DOMES, "chronograph," which at Greenwich is on

The chronograph is a cylinder ou which paper is fixed, and on paper is registered the times of the stars'

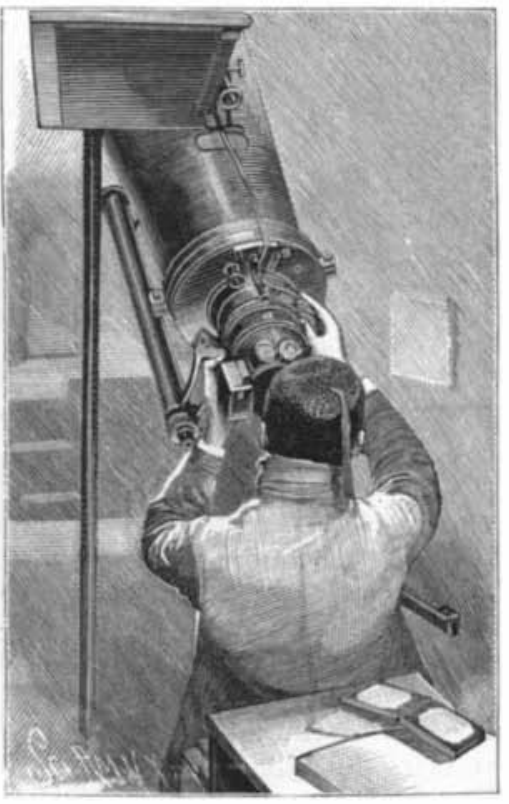

TAKING AN OBSERVATION, 
transit across the fine lines of the telescope. It can the last few years, however, the sources of this numeralso register the seconds of a sidereal clock. By this ous host.

system of registering the transit of stars greater ac- Part of them, a small part, come from the air; part curacy is gained and also greater time is permitted to the observer to gaze through the telescope.

But it may still be asked, Why are stars selected to tell the time? Because, for one very potent reason, there is but one sun, and there are so many stars; therefore, so many more chances of good observation. There are very few nights on which scme of the 250 clock stars used at Greenwich are not observable. Further, the observations on the various stars may be
used to check one a nother and correct errors, while but one observation of the sun on the meridian can be made.

But how can the passing of the star over the meridian tell the time? In this way: The complete turning round of the earth on its own axis cause a day anc night, that hair of cal language, form one day. If, then, a certain star be large amount of dust and dirt. All of the dirt and on the meridian at such a time, it should be on the manure is crowded with innumerable hosts of bacteria meridian again, after a lapse of twenty-four hours, at Again, the milk ducts of the cow's teats form a prolific precisely the same time; and the clock, to bə accurate, ! breeding place for the bacteria. After each milking should agree. The earth has made one complete turn some milk is left in the wilk ducts, and in this the round, one complete rotation, and one complete day bacteria which may get to teat from the air or the and night have passed. This is termed a sidereal day, dirt or hairs of the cow find abundant food. Here and it is regarded by astronomers as always of the same they multiply, and by the time of the next milking and it is regarded by astronomers as always of the same space of time, because the
garded as exactly uniform.

The solar day or solar time is measured by the pas. sage of the sun day after day across the meridian, and is four minutes more than the sidereal day. Further, the solar day differs somewhat in length, through the movements of sun and earth; thus the earth moves more quickly in winter than in summer; and these differences are allowed for by astronomers in calculating time. The result is what is called "mean" time. The reason of the difference of four minutes is that one revolution is added to the diurnal revolutions of the earth on its axis, in consequence of its revolution around the sun in its orbit, so that while there are in round numbers 365 days in the solar year, there are 366 sidereal days. The four minutes per day difference, therefore, makes in the year another whole day, that
is, 24 hours 20 minutes. Four minutes saved or lost in a day, you see, make up a whole 24 hours at the end of the year.

But the keeping of the time is not the only work that is done at the observatory. There are ten great
telescopes, the largest one being nearly 30 feet long telescopes, the largest one being nearly 30 feetlong,
with an object glass of 28 inches. Over this is a beautiful dome, made like the others of papier mach stretched over iron framework. This gives lightress and strength, enabling the dome to be easily worked on wheels. One portion, opened like a sliding shutter, reveals a strip of sky from the zenith to the horizon; sky can be easily and speedily brought under observation.

The large telescope is devoted to the stupendous work of photographing the heavens. About a dozen observatories are engaged in this truly gigantic task, each having a certain portion allotted to it.

All is remarkably quiet at the observatory, Greenwich. Day after day and night after night the obserrations go forward and the calculations are made. ducing by calculation the various observations that

have been made.
For anything I have been able to say, I am indebted to the astronomer roval and his able assistants; also to those who like myself have visited the royal observatory at Greenwich and made notes, and
by comparing notes have been assisted in reaching accuracy.

\section{Bacteria in Milk.}

time and undergoes a process which we call ripening Bacreria are plants of almost inconcei vably minute or which is in some parts of the world simply called size. So small are they that in some cases $50,000 \mathrm{might}$ : souring. During this ripening the cream acquires a length of an inch. They are extremely simple also. This ripening is nothing a peculiar pleasant odor. Some of them are simple balls, others are short cnes due to the growth of the bacteria which are in the and others still are of a spiral shape. But although cream. During this twenty-four to forty-eight hours thus very small and simple in structure, their powers the bacteria which were in the cream multiply rapidly, of multiplication are so great as to make them factors until at the close of the ripening there may be as many
of profound signiticance in the processes of nature. as $2,400,000,000$ per cubic inch. This growth produces of profound signiticance in the processes of nature. as $2,400,000,000$ per cubic inch. This growth produces
So rapidly can they multiply that in some cases a a fermentation, just as the growth of yeast in the So rapidly can they multiply that in some cases a
single individual in the course of twenty-four hours may produce nearly twenty million offspring. This power of multiplication is so enormous we must not be surprised to find them capable of accomplishing by their growth many great changes in nature.

Pure milk, as it is secreted from the udder of the Pure wilk, as it is secreted from the udder of the
kealthy cow, contains no hacteria. If the cow be diseased, this may not be true, but the milk from the healthy now contains no bacteria when first secreted.
Nevertheless, by the time the milk reaches the milk pail it will contain from 30,000 to $5,000,000$ bacteria pe cubic inch. It is hardly conceivable that the few moments of the milking should be sutficient to con-
taminate the wilk to this extent. We have learned in *By, Prof. B. W. Conn (of the Biological Department, Weslegan Univer-
Bity), in the Spatadis cream and to the subsequent butter. After they have developed in the cream, the churning simply separate the butter already flavored with these products. the gifts to the butter maker from the bacteria of the ripening period.

To make good butter, the butter maker needs not only the freedom from the species of bacteria which produce unpleasant flavors, but he needs also the presence of the species which produce the desired flavors. Butter made from cream that comes from the cleanly kept dairy may be depended upon not to develop the unpleasant flavors which arise
cream from the filthy dairy and barn.

But to insure the proper number of proper flavorBut to insure the proper number of proper favor-
producing species simple cleanliness is not so much to producing species simple cleanliness is not so much to
be depended upon. In many such cases it is true the be depended upon. In many such cases it is true the
proper flavor-producing species will be present, but not always. But why is it not possible to directly inoculate the cream with the proper flavor-producing
species, just as the brewer inoculates his malt with pecies, just as the brewer inoculates his malt with
yeast? This does, indeed, a ppear not only to be possible but perfectly feasible, and it involves the use of what are now known as starters. The starter is simply a lot of cream or milk containing a large number of bacteria, which is poured into the cream to be ripened to start the proper kind of fermentation. The starters are of two kinds. Natural starters, which are easily made by any butter maker, and artificial starters, which are made upon a different plan. Our bac-
teriologists, both of this country and Europe, have been searching for proper flavor-producing species and having found them, they propose to furnish them in quantity to the butter waker for use in his cream ripening. In the use of these starters the species of grow in a small lot of crean until its species is very abundant and then the cream is added to the large vat as a starter. The result is that the butter maker vat as a starter. The result is that the butter waker
can always depend upon having present a quantity can always depend upon having present a quantity
of the proper flavor producing species, and can, therefore, depend with more certainty upon the product This method of using artificial starters is not new. It has been adopted in Denmark and some other countries of Europe to a wide extent. In this country
has been used only for about a year, and is only just coming to be recognized as a proper method of butter making. The bacteria favorable for this purpose are now upon our markets, two or three different ones benow upon our markets, two or three different ones be-
ing now used in this country. They are generally known as pure cultures, a term which simply means a large quantity of one species of bacteria unwixed with thers. The bacteria are even more needed in cheese mak-
ing than in butter making. A fresh, flat, curdy taste is seen in fresh cheese. The cheese to be marketable must be set aside for a few weeks to ripen, and during is simply a fermentation. It is a fermentation of a different character from that of cream ripening. It different character from that of cream ripening. It
takes place wore slowly and the products are of a different nature, but it is none the less due to the growth of bacteria, and the different flavors of different cheeses are due to the growth of different kinds of bacteria in the cheese. But the problem has proved a difficalt one to handle, and while the general facts are easily made out and are demonstrated beyond question, very little in the way of practical results has as yet
been reached. A future in this line can hardly be questioned.

nected with dairy matters, it is always as the caus airvman really benefits from them more than he suf ers. Their beneficial effects are shown upon at lea wo important dairy products, butter and cheese.

\section{The World's Wine Production.}

The Moniteur Vinicole has recently published statement showing the wine production of the various countries of the world. From this statement it appears the yield in France amounted in the years 1895 and 1894 to $587,127,000$ gallons and $859,162,000$ gallons respectively; in Algeria to $83,549,000$ and $80,124,000$ gal-
lons. Tunis, $3,956,000$ and $3,936,000$. Italy $469,555,000$ and $539,000,000$; Spain, $379,500,000$ and $528,000,000$ Portugal, 43,890,000 and 33,000,000; Azores, Canaries, and Madeira, 4,620,000 and 2,640,000; Austria, 66,000 000 and $88,000,000$; Hungary, 63.030.000 and 46,103,000; and Germany, 80,190,000 and 110,000,000 gallons. In Turkey and Cyprus the production last year awounted to $52,800,000$ gallons, and this compares with an average vield of $40,000,000$ gallons. In Bulgaria the yield was
$26,400.000$ gallons; Servia. 17,600,000; Greece, 35,200 . The object of this ripening is at least threefold.
First, it makes the cream chun more readily, and, Roumania, $68.640000 ;$ Switzerland, 27,500,000
the United States, 89.700.000; Mexico, 1,980,000; Argensecond, it gives a larger amonnt of butter from a given tine Republic, 29,700 000; Chile, 33,000,000; Brazil, lot of creain. The third object is to give flavor to the 7,700,000; Cape of Good $\mathrm{H} \circ$ pe, 2,420,000; Persia,
butter. The explanation of the flavor is simple enough. '594,000; and Australia, 3,300,000 gallons.

While the bacteria are growing in the cream they are producing, as they are feeding upon it, certain chemical changes in it. As the result of these chemical Many of our readers will be glad to know that the long hanges decomposition products are developed, and expected distribution of Columbian World's Fair diplothese products have various flavors and odors. If the mas and medals has begun. On April 20 a consideraripening is allowed to continue long enough, the whole ble number of diplomas and medals were given to Baron mass becomes decayed and the flavors and tastes are Thielmann, the German ambassador, for distribution composition, instead of being unpleasant, are decidedly will be ready for delivery in a short time. The excesagreeable, and it is these which give flavor to the sively long delay is to be deeply regretted. 
Largest and Smallest Books.

Prof. Max Muller, of Oxford, in a recent lesture, has (n) book in the world, the wonderful "Kuth Daw." It consists of 729 parts in the shape of white marble plates, covered with inscrip- f tions, each plate built over with a temple of brick. It is found near the old priest city of Mandalay, in Burma and this temple city of more than seven hundred pagodas virtually makes up this monster book, the religious codex of the Buddhists. In accordance with the three parts of which it is composed, generally called in a figurative sense "baskets" (pitaka), the whole is often termed "the three baskets" (tripitaka), and constitutes a library larger than the Bible and the Koran together. As the Jews figured out that the Old Testament contained 59,493 words and 2,728,100 letters, so the Buddhist priests have computed that the "Tripitaka" contains 275,250 stanzas and 8,808,000 syllables. This monster book is written in Pali. Rather strange to say, it is not an ancient production, but its preparation was prompted by the Buddhistic piety of this century. It was erected in 1857 by the command of Mindowin, the second of the last kings of Burma. As the influence of the tropical climate has already marred the inscriptions, a British official, Mr. Ferrars, proposes to have these 729 plates carefully photographed, and asked that the government or photograph and a d a for this. Prof. Muller urges that this be done in order to preserve at least the pictures of this unique templecity book.

A noteworthy contrast is furnished by a recent German literary journal describing what is probably the smallest book in the world. This is a "Konversationslexikon," published in Berlin, and prepared by Daniel Sanders. The volume occupies the space of only six cubic centimeters $(0.366$ cubic inch $)$ although it is read through a microscope especially prepared for it. Mining and Scientific Press.

\section{INGLAND AND THE SOUDAN.}

For the accompanying pictures of Soudanese women and warriors, reproduced from photographs by Dr Jousseaume, we are indebted to Le Monde Illustré. The Soudan includes, in a general way. all the territory south of Nubia and the present British possessions in Egypt to the equatorial lakes, and from the Red Sea on the east to the desert on the west. It is estimated to have a population of from five to seven millions, and is ruled over by the Mahdi, whose seat of government is at Omdurman, and whose lieutenant. government is at Omdurman, and whose lieutenant.
Osman Digna, has uade frequent raids into the English territories in upper Egypt. To strengthen and possibly ad vance their frontier, a British expedition of some 9,000 native Eryptian troops, and a contingent of British soldiers, is now ad vancing up the Nile,although it is not expected that the most serious part of the campaign will begin until September or October,
when the rise of the Nile will permit the carrying of when the rise of the Nile will permit the carrying of
supplies for the troops up the river in boats. It is supplies for the troops up the river in sand men under arms-a force which they could vastly first through the pressure of the pneumatic tire, which 作 sirable. Famine, disease, the slave trade, and war|any tossing about. As a further measure of precau- ated at Niagara Falls and transmitted to New Yurk a mong the tribes of the Soudan are reported to be thinning out the poplating the por

H. Moissan describes two n e w metallic borides, says $\mathrm{t}$ h e Comptes Rendus, ob tained at a temperature of temperat ise of boride, NiBo, and cobalt boride, CoBo. Both oceu r in brillian prisms several millimeters in length and are mag netic.

Their densities at $18^{\circ}$ are about the samenickel boride, 7'39: cobalt b ori d e, 725 The propertie of the borides are analogous to those of iron boride, and the compounds
TYPES OF WOMEN AT KHARTOUM

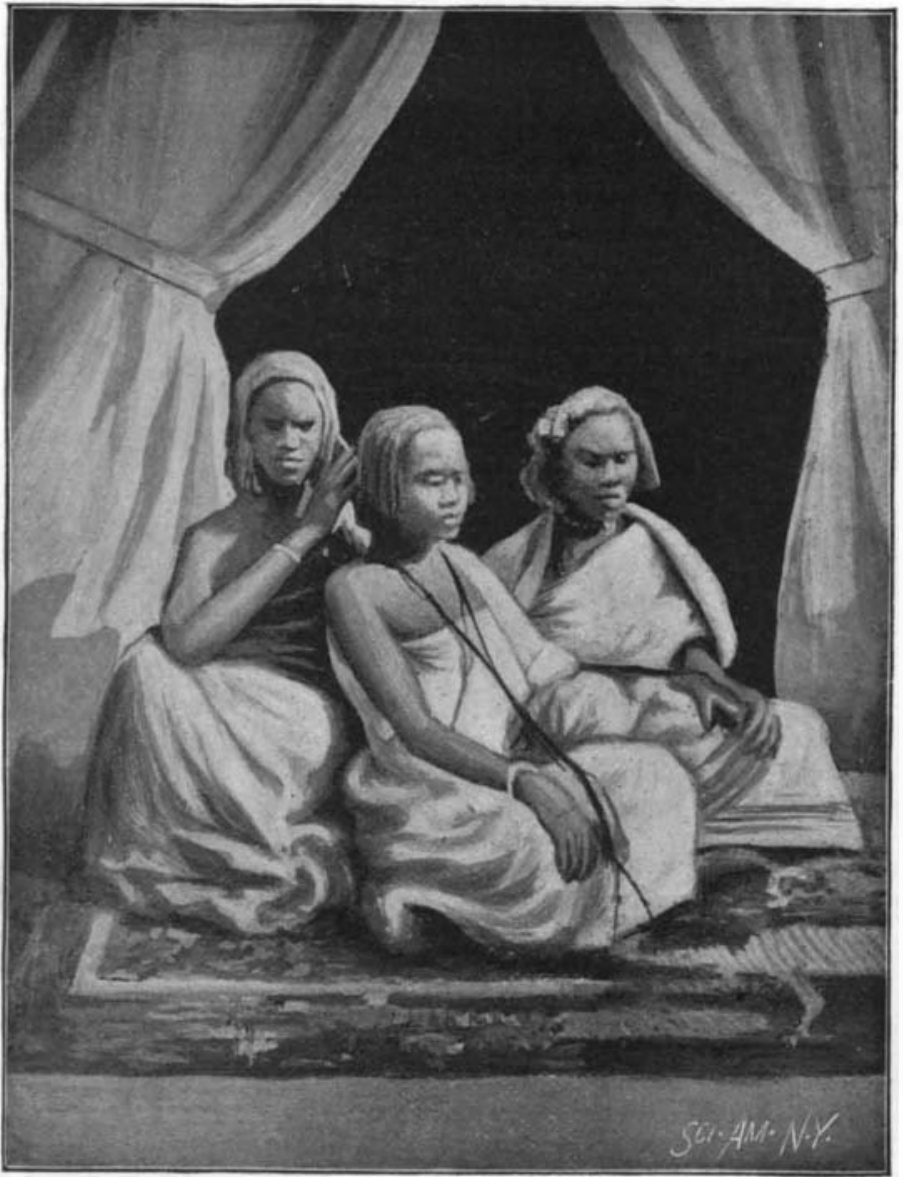
by a strap that passes Company. Telephones will be connected with instruments at $\mathrm{Ni}$

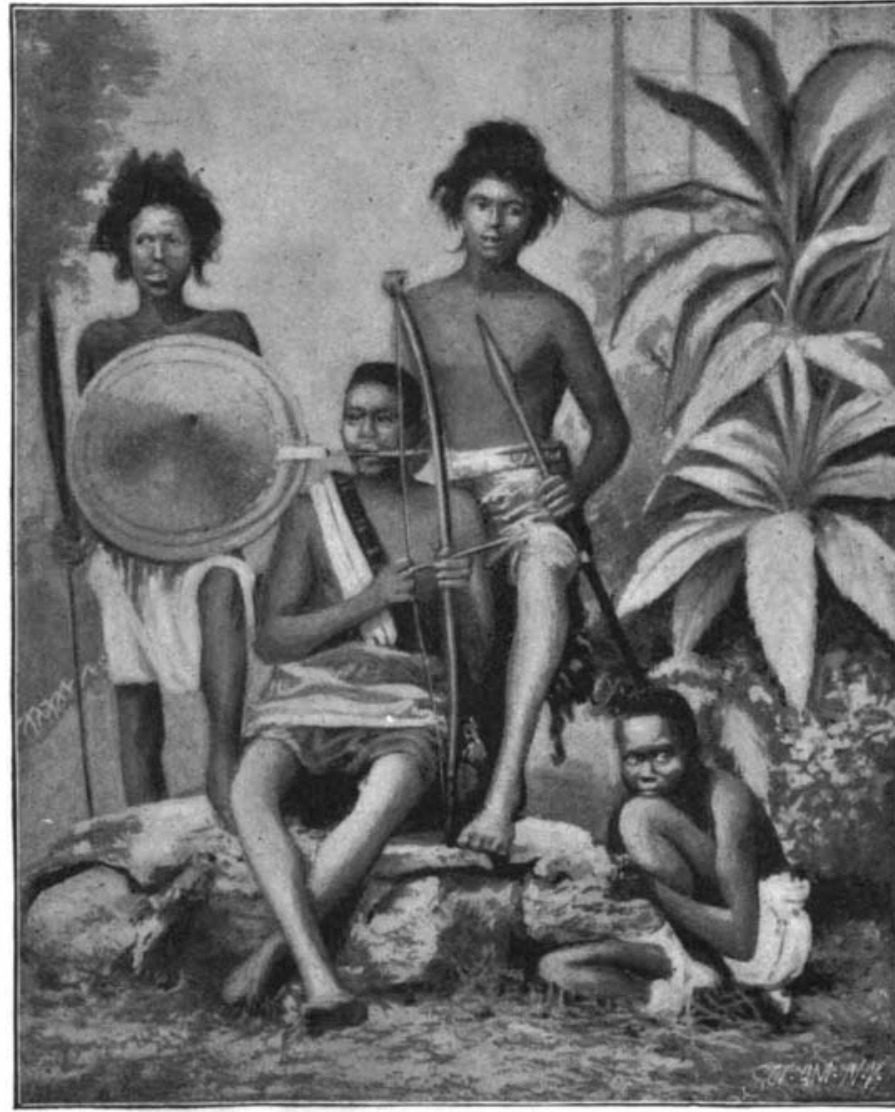

SOUDANESE WARRIORS. agara, so that falls may be heard. It is also said that some steps are being taken to deliver some of the current to condensers an Atlanti cable, so that the power of Niagara way be transmitted to Europe.

Dr. Holden, of the Lick Observatory, has coration of the Order of Boli$\operatorname{var}$ (of Venezuela) for his dis services to sc: ence. $\mathrm{He}$ ha previously re ceived the decoration of commander or Order of Saxony. 